\title{
Results of Five Years of Integration of Leprosy Control into the Provincial Health Service of Phuket Island, Southern Thailand
}

\author{
TEERA RAMASEETA, SURASAK SAMPUTTAVANICH \\ AND PRACHUMPEL OCHASANENDHA \\ Leprosy Division, Department of Communicable Disease Control, \\ Thailand \\ and \\ TONETARO ITO \\ Department of Leprology, Research Institute for Microbial Diseases, \\ Osaka University, Japan
}

\begin{abstract}
Five years experience of integration of leprosy control in Phuket Island, Southern Thailand, showed that known cases of leprosy had increased by $251 \%$ from 0.77 to 1.93 per thousand, through the efforts of local health workers, and by $318 \%$ from 0.75 to 2.45 per thousand on a second survey conducted in the fifth year of integration. Local health workers detected $43 \%$ of total registered cases, remaining cases being found by a specialized leprosy survey team.

The accomplishment of 3 main targets in leprosy control, namely treatment, contact examination and bacteriological smears had gradually declined by $35 \%$ from 66 to $31 \%$ indicating a great need for better supervision and motivation. Adequate survey before integration was also necessary, followed by regular supervision and field guidance to promote proper efficiency and effectiveness of leprosy control.
\end{abstract}

\section{Introduction}

The Phuket Province is one of the smallest and most hyperendemic in leprosy of the 14 provinces comprising the Southern Region of Thailand. It is an island with an area of $801 \mathrm{~km}^{2}$ where 103,262 inhabitants live in 3 districts with little mobility of population. The existing health structure covers every area, and the health workers are well motivated. Because of its strategic position in the Region and its available health facilities, Phuket Province was chosen as the pilot province for integration of leprosy control into the Provincial Health Services.

Within 5 years of the integrated leprosy control services, registrations of patients increased from 91 in 1972 to 253 cases in 1976, which brought up the 
prevalence in Phuket Island to 2.45 per thousand, being highest in the South. In 1976, with the support of the Sasakawa Memorial Health Foundation of Japan and the technical advice of the World Health Organization, the Leprosy Division of the Department of Communicable Disease control of Thailand conducted a stratified random sampling survey to assess the epidemiological situation and to evaluate certain aspects of the integrated central operations.

\section{First Survey and Orientation Training Prior to Integration}

In 1972, prior to the launching of integration, the Leprosy Division sent a survey team to conduct selective case finding procedures, which included the examination of all known cases, suspects, household contacts and school children. Health education was also conducted on local radio to stimulate voluntary presentation for examination at the Provincial Health Office. The survey lasted about 3 weeks. Eighty-seven leprosy cases were detected and registered with an overall point prevalence of 0.77 per thousand and a lepromatous rate of 0.44 per thousand.

After the survey, a 3 day orientation training course prior to in tegration was given to 2 groups of 54 provincial health workers. Subsequently, patients were then delegated to the health workers in charge of the existing 14 health centres and 3 midwifery centres. Seven main targets in leprosy control service were assigned to each of the workers. These were as follows:

(a) To carry out examination for leprosy of people voluntarily attending all health and midwifery centres.

(b) To give monthly treatment to all registered cases at the minimal annual treatment rate of $75 \%$.

(c) To examine household contacts once a year at the minimal annual examination rate of $60 \%$.

(d) To examine school children once a year at the minimal annual examination rate of $20 \%$.

(e) To make bacteriological smears of all lepromatous (including borderline) and newly detected cases once a year at the minimal annual smear rate of $60 \%$.

(f) To send a monthly report on leprosy control activities.

\section{Second Survey}

The second survey of the province was undertaken in 1976 by the authors. A total of 90 villages in rural areas were covered by the survey and the sampling unit was half of the households of each village (50\%). The method of stratified random sampling was used, picking out labels with odd or even numbers. If odd No. 1 was drawn, the survey would be carried out in households Nos. 1, 3, 5, 7, 9 . . etc., house after house, and vice versa for even numbers, until the target was reached. The survey took 3 months, and a total population of 31,350 were examined from 5,301 households $(51.63 \%)$ out of a total 10,268 households in a total population of 62,564, and an approximate $51.6 \%$ sample and $97.03 \%$ coverage of target population were obtained.

Since the method used for the first survey was not the same as that in the second survey, it is not intended in this report to compare the results of these twc. surveys, but to use the result of the second one as basic data to be in every way comparable to future surveys, using the same frame of households and methods. 
The results of the second survey revealed a detection of 31 leprosy cases, a detection rate of 0.99 per thousand with lepromatous cases 0.25 per thousand. When comparing the detection rate of Phuket with the assessment at Khonkaen conducted by the WHO Headquarters Leprosy Advisory Team (L.A.T.) in 1962 and 1972, the most important conclusion which can be drawn from this data the lepromatous detection rate, detection of lepromatous cases among newly detected cases, and prevalence of old leprosy cases are comparable in Khonkaen and Phuket, even though the duration of control operations was completely different (Table 1).

TABLE 1

Comparison of results of epidemiological survey of Khonkaen in 1962, 1972 and Phuket in 1976

\begin{tabular}{|c|c|c|c|c|c|c|}
\hline Provinces & $\begin{array}{c}\text { Year } \\
\text { conducted }\end{array}$ & $\begin{array}{l}\text { Duration } \\
\text { of leprosy } \\
\text { control } \\
\text { project } \\
\text { prior to } \\
\text { assessment }\end{array}$ & $\begin{array}{c}\text { Prevalence } \\
\text { of old cases } \\
\text { per thousand } \\
\text { in assessment } \\
\text { year }\end{array}$ & $\begin{array}{l}\text { Detection } \\
\text { rate of new } \\
\text { cases per } \\
\text { thousand }\end{array}$ & $\begin{array}{l}\text { Detection } \\
\text { rate of newly } \\
\text { lepromatous } \\
\text { cases per } \\
\text { thousand }\end{array}$ & $\begin{array}{c}\text { Proportion } \\
\text { of newly } \\
\text { detected } \\
\text { lepromatous } \\
\text { cases }(\%)\end{array}$ \\
\hline Khonkaen & $\begin{array}{l}1962 \\
1972\end{array}$ & $\begin{array}{r}7 \\
14\end{array}$ & $\begin{array}{l}8.51 \\
2.88\end{array}$ & $\begin{array}{l}3.86 \\
1.42\end{array}$ & $\begin{array}{l}0.30 \\
0.21\end{array}$ & $\begin{array}{l}7.8 \\
8.82\end{array}$ \\
\hline Phuket & 1976 & 5 & 1.93 & 0.99 & 0.18 & 19.35 \\
\hline
\end{tabular}

TABLE 2

Clinical classification of new leprosy patients found from the second survey of Phuket

\begin{tabular}{lccccc}
\hline \multicolumn{1}{c}{ Area } & Indeterminate & Tuberculoid & Borderline & Lepromatous & Total \\
\hline $\begin{array}{l}\text { Sampling households } \\
\text { in rural area }\end{array}$ & 8 & 15 & 2 & 6 & 31 \\
$\begin{array}{l}\text { Outside the sampling } \\
\text { households in rural }\end{array}$ & 2 & 12 & 1 & & \\
$\quad$ area & 1 & 6 & 0 & 1 & 8 \\
$\begin{array}{l}\text { In-municipal area } \\
\text { Total }\end{array}$ & 11 & 33 & 3 & 7 & 54 \\
\hline
\end{tabular}

The classification of new cases found on survey is set out in Table 2. Of the 31 new cases found in the sampling households in rural areas, 8 were indeterminate, 15 were tuberculoid, 2 were borderline and 6 were lepromatous. This figure might be of value as baseline data for future survey. Besides 31 new cases found in the sampling households, 15 and 8 new cases were also detected from outside the sampling households in rural areas and municipal areas respectively. These total 54 new cases found in 1976 indicated inadequate case detection effectiveness by local health workers.

\section{Sub-district Prevalence}

The present prevalence of leprosy by sub-district (Tambol) together with the prevalence found in 1972, is shown in the map given as Fig. 1. The highest 


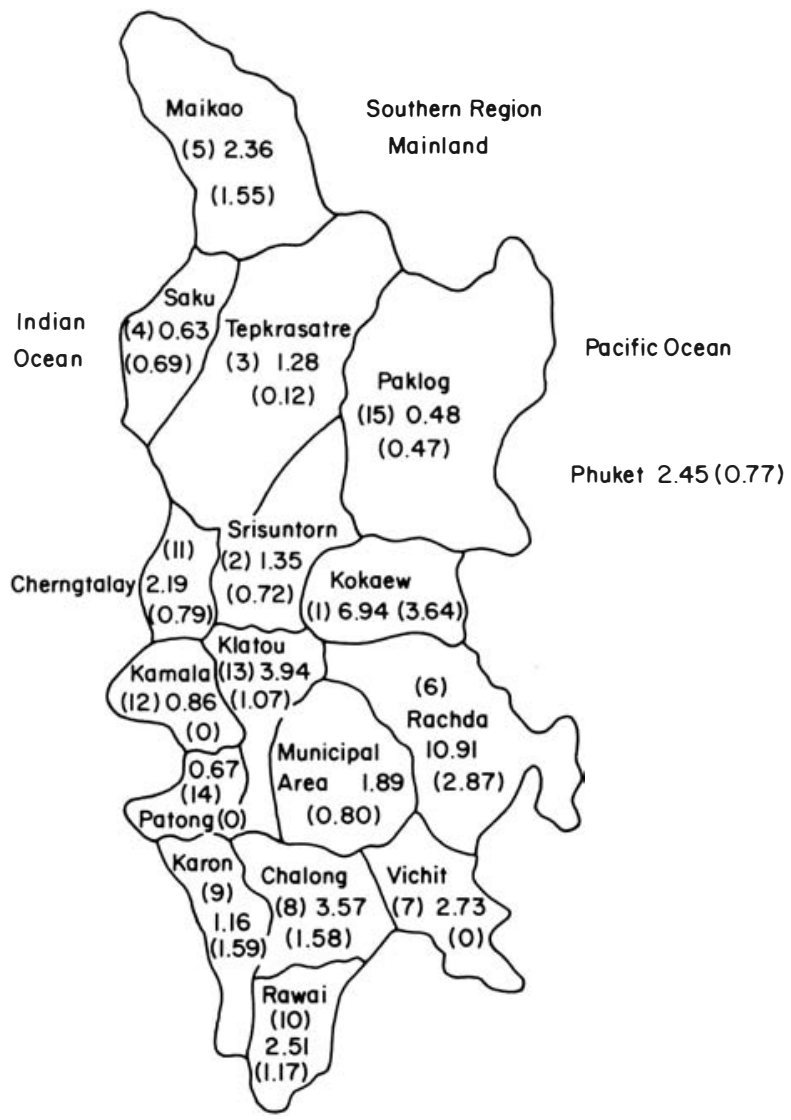

Fig. 1. Phuket Island showing prevalence of leprosy per thousand by subdistrict (Tambol) in 1976; figures in brackets, leprosy prevalence-1972.

prevalence rate (10.91 per thousand) was in Tambol 6 (Rachda) while the lowest prevalence rate $(0.48$ per thousand) was in Tambol 15 (Paklog).

An increase in point prevalence had occurred in almost all subdistricts (Tambol), but it was most remarkable in Tambol 1 (Kokaew) and Tambol 6 (Rachda), both of which had increased from their previous hyperendemic level of prevalence to well above 5 per thousand. Both Tambols have special tribes of seamen, so called "Chaoley" whose living standard and education are rather low. Total survey of two hyperendemic villages in these 2 Tambols was carried out by the assessment team, with $95.57 \%$ population examined. The results showed an increase of prevalence from 52 and 119 per thousand to 56 and 139 per thousand respectively. Since there are now good communications and health structures covering all Tambols, with adequate field guidance and supervision, it is hoped that higher standards of case holding will be achieved here in the future. 


\section{Operational Assessment}

\section{CASE FINDING}

The annual detection of new cases, both overall and for lepromatous cases is shown in Fig. 2.

The overall case finding showed that out of a total 253 cases detected in the 5 year integrated programme, $87(34.39 \%)$ were found from the first survey and 54 (21.3\%) were found from the second survey, while local health workers themselves detected 112 cases $(44.24 \%)$. It is therefore important to conduct adequate case finding programmes before integration of leprosy control into the local health service. However, if 87 cases found from the first survey were excluded, it is noteworthy that $67.47 \%$ of newly registered cases in Phuket af ter total integration were detected by local health workers, therefore, their diagnostic capability should be highly evaluated.

With regard to the mode of case finding (Fig. 3), voluntary case detection was

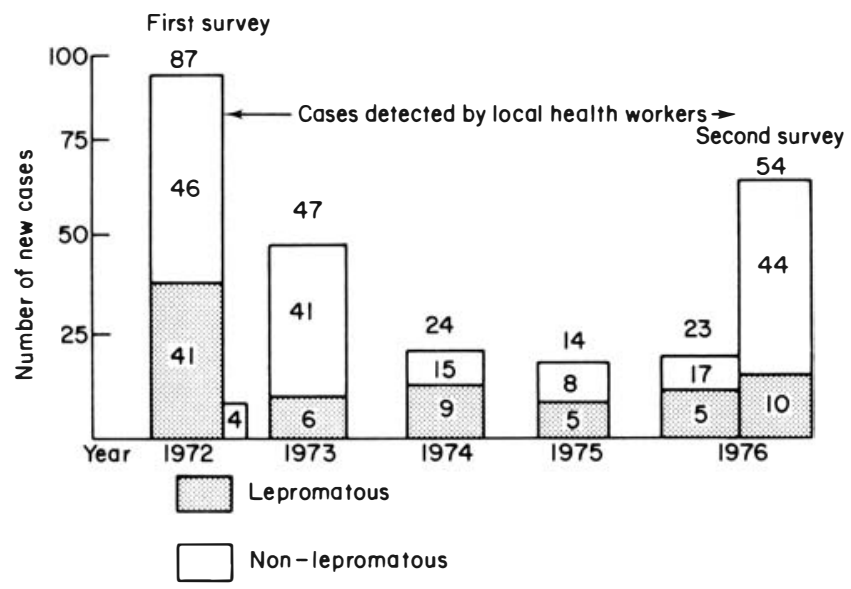

Fig. 2. Annual detection of new cases of leprosy in Phuket, 1972-1976.

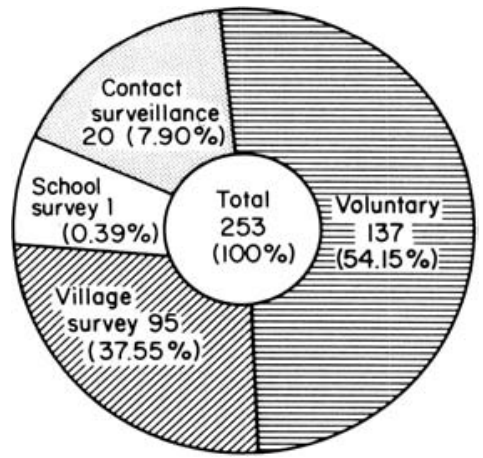

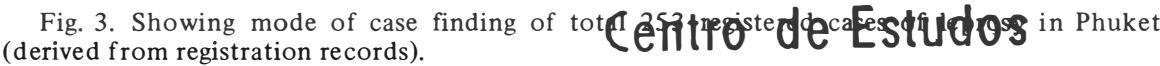


TABLE 3

Clinical assessment of 163 old registered cases of Phuket

\begin{tabular}{|c|c|c|c|c|c|c|c|c|c|}
\hline \multirow[b]{2}{*}{ Type } & \multirow{2}{*}{$\begin{array}{l}\text { Total } \\
\text { number of } \\
\text { registered } \\
\text { cases }\end{array}$} & \multirow{2}{*}{$\begin{array}{l}\text { Number } \\
\text { of } \\
\text { cases } \\
\text { examined }\end{array}$} & \multirow[b]{2}{*}{ Active } & \multirow[b]{2}{*}{ Inactive } & \multicolumn{3}{|c|}{ Condition of cases } & \multirow[b]{2}{*}{ Dead } & \multirow{2}{*}{$\begin{array}{c}\text { Transfer } \\
\text { out }\end{array}$} \\
\hline & & & & & Released & Misdiag & Misclassification & & \\
\hline Indeterminate & 18 & 13 & 3 & 7 & 2 & 3 & 0 & 0 & 3 \\
\hline Tuberculoid & 112 & 100 & 62 & 38 & 2 & 0 & 13 & 0 & 2 \\
\hline Borderline & 1 & 1 & 1 & 0 & 0 & 0 & 1 & 0 & 0 \\
\hline Lepromatous & 68 & 49 & 32 & 17 & 0 & 0 & 6 & 1 & 1 \\
\hline Total & 199 & 163 & 98 & 62 & 4 & 3 & 20 & 1 & 6 \\
\hline
\end{tabular}


found to be very high (54\%) while village survey detected $37 \%$ of cases. The high percentage of voluntary cases indicates the value of using health education through radio and bringing treatment close to the patients, but it is also evident that there is still a limited coverage. Contact surveillance has been one effective tool to detect cases. School surveys have appeared, on the whole, not to have been very productive as a routine measure, and more selection in the school, for instance those located in hyperendemic areas, would probably be economical.

\section{CLINICAL ASSESSMENT OF 163 OLD REGISTERED CASES}

A clinical assessment of 163 old registered cases had been made by the second-survey team, the results of which are shown in Table 3.

In the present assessment, only mis-diagnosis of 3 indeterminate cases $(2.68 \%)$ was found. As local health workers officially registered all leprosy cases detected, the low instance of mis-diagnosis, therefore, indicated high efficiency of their training and diagnostic capability. The high proportion of inactive cases indicated the successful treatment by integrated leprosy control services. The epidemiological importance of these patients has thus been greatly reduced. The instance of misclassification indicated the need for closer field supervision and guidance, by which a higher number of released cases will also be obtained.

\section{TREATMENT, CONTACT-SURVEILLANCE AND BACTERIOLOGICAL SMEARS}

The degree of accomplishment of 3 main targets of integrated leprosy control activities is shown in Fig. 4.

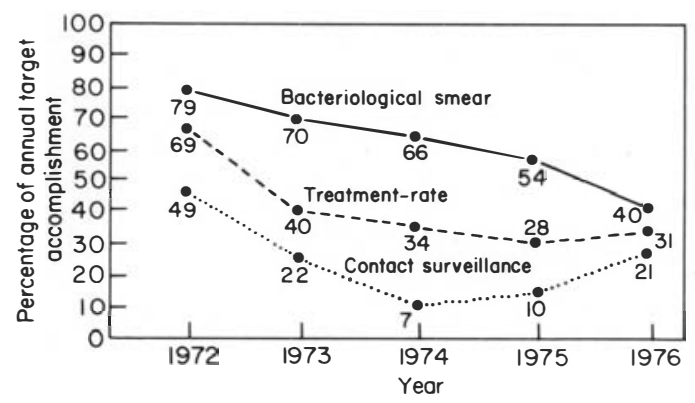

Fig. 4. Showing annual accomplishment of 3 main targets of integrated leprosy control in Phuket, 1972-1976.

The 3 main targets of leprosy control activities, on the whole, were below the standard requirement (treatment rate $75 \%$ ), contact examination $60 \%$ and bacteriological smear $60 \%$ ), and are not improving. This indicates reduction in interest and willingness of local health workers, and also reflects inadequate supervision. An effort to improve supervision and motivation, therefore, is urgently needed. Further operational study research might be also of great value, so that the result could be applied to other Provinces in Southern Thailand.

\section{BACTERIOLOGICAL STATUS OF “OPEN” CASES}

Sixty-eight lepromatous cases registered and treated since 1972 were analysed in respect of their bacteriological status and duration of treatment. This revealed 
that 33 cases (48\%) who had received treatment for period ranging from 1 to 5 years were still bacteriologically positive by standard skin smears. For the 37 cases who received treatment for fully 5 years, 13 cases (38\%) were still positive. In comparison, figures from Khonkaen Province of North-east Thailand, were 37 and $14 \%$ respectively. Irregular attendance for treatment might be one of the main factors causing such a difference.

\section{Acknowledgements}

The authors would like to thank the Director-General, Department of Communicable Disease Control, Ministry of Public Health, Thailand for allowing us to conduct this field study. Particular thanks are due to the Sasakawa Memorial Health Foundation for financial support to the second evaluation survey and also to the Leprosy Unit of WHO Headquarters, Geneva for technical advice.

\section{References}

World Health Organization (1963). WHO Leprosy Advisory Team, Report on Leprosy Survey in Thailand, Unpublished.

World Health Organization (1972). Assignment Report on Assessment of Leprosy Control Services in Thailand, WHO Project: Thailand 0059, Unpublished.

Pakdi, A. C., Sanyakorn, C. K. and Seal, K. S. (1974). Some results from sixteen years of leprosy control work in the Khon Kaen Province of N.E. Thailand. Lepr. Rev. 42, 205.

Kettanurak, C., Ramasoota, T., Kongsoebchat, K. and Sampattavanich, S. (1973). Preliminary report on the pilot project of early total integration on leprosy control into Local Health Services at Phuket Island, Thailand. Int. J. Lepr. 41, 622. 